\title{
TANGGUNG JAWAB AWAM DALAM PERUTUSAN DIAKONIA GEREJA
}

\author{
Norbertus Jegalus \\ Doktor dalam Bidang Filsafat, Program Studi Ilmu Filsafat, Fakultas Filsafat, \\ Universitas Katolik Widya Mandira Kupang \\ Email: norbertus2306@gmail.com
}

\begin{abstract}
Laymen in the Church have an unique mission in the world. They are sent by Christ the Lord to transform the world with the christian values. They have a great responsability in spreaching the Gospel to all people. In cooperation with the clergy, they should realize Jesus' teaching of love in the act of loving to each other, especially the sick, the poor, the suffer. They should promote human rights, justice, peace and common wealth in the society where they live. This is their mission based on the faith, Gospel and The Social Teaching of the Church. This mission is a form of diaconia of the laymen in the Church.
\end{abstract}

Keywords: Umat beriman kristiani, kaum awam, diakonia, Gereja, keadilan

\section{Pendahuluan}

Kerangka perutusan Gereja dapat kita gambarkan demikian: Gereja adalah sebuah persekutuan (koinonia) orangorang yang mengimani Yesus Kristus. Anggota-anggota Gereja yang mengikuti Yesus Kristus itu dipanggil untuk mewartakan Injil Yesus Kristus, dan itulah yang kita sebut kerygma. Begitu pewartaan itu diterima, maka dirayakan dan diungkapkan dalam doa, dan itulah yang kita sebut leitourgia. Begitu doa dan liturgi itu berfungsi dengan baik, maka persekutuan beriman itu, baik secara perorangan maupun secara bersama, digerakkan untuk terlibat dalam tindakan nyata melayani sesama dengan semangat kasih, dan itulah yang kita sebut sekarang perutusan diakonia. ${ }^{1}$

Ketiga tugas itu adalah perwujudan tritugas Yesus Kristus sebagai Nabi, Imam, dan Raja, yang dijalankan oleh semua anggota Gereja baik tertahbis maupun tak tertahbis (awam). Dengan perutusan diakonia Gereja menjadi sungguh nyata. Karena, dengan diakonia, yaitu perbuatan pelayanan

\footnotetext{
${ }^{1}$ Bdk. Ensiklik Deus Caritas est 25.
} 
kasih, Gereja atau persisnya anggotaanggota Gereja memberi kesaksian tentang keselamatan Allah sebagaimana nyata dalam hidup sehari-hari di tengah masyarakat. Dalam konteks itulah kita berbicara tentang tanggung jawab kaum beriman. Dengan perutusan diakonia ini iman kaum awam tidak lagi sekadar urusan keyakinan yang bersifat bathiniah dan personal melainkan menjadi sekaligus keyakinan yang bersifat lahiriah dan publik.

Untuk itu, berikut ini, kita terlebih dahulu melihat sepintas poin-poin penting teologi tentang awam Konsili Vatikan II; lalu atas dasar paham itu kita mengangkat dua persoalan sosial saat ini, yakni ketidakadilan dan korupsi; dan akhirnya kita berbicara tentang wujud tanggung jawab awam Katolik terhadap kedua masalah sosial itu. Berbicara tentang wujud tanggung jawab kaum awam berarti berbicara tentang tindakan nyata kaum awam, dan tindakan itu dilakukan berdasarkan inspirasi Injil dan prinsip-prinsip pembimbing dari Ajaran Sosial Gereja.

\section{Sedikit Teologi tentang Awam}

\section{Pengertian Awam}

Pengertian tentang awam tidak dimuat di dalam dokumen khusus tentang kerasulan awam, Apostolicam Actuositatem, melainkan di dalam dokumen konstitusi dogmatis tentang Gereja, Lumen Gentium. Bapa konsili berusaha membuat suatu defnisi tentang awam, meski tidak merupakan sebuah definisi real essensial sebagaimana dituntut oleh logika, melainkan hanya sebuah deskripsi tipologis: "Yang dimaksud dengan kata awam di sini ialah semua orang beriman kristiani kecuali mereka yang termasuk golongan rohaniwan atau status kebiaraan yang diakui di dalam Gereja".2 Jadi, yang disebut awam adalah orang beriman kristiani yang bukan imam dan bukan juga biarawan.

Dari deskripsi tipologis itu kita tahu bahwa di dalam Gereja terdapat tiga golongan orang beriman Kristen, yaitu golongan imam (clerus), golongan biarawan (religius), dan golongan awam (laicus). Dengan ini konsili mau

2 T. Jacobs, Konstitusi Dogmatis "Lumen Gentium" mengenai Gereja. Terjemahan Introduksi Komentar, Jilid III, Yogyakarta: Kanisius, 1974, hlm. 594-595. 
menekankan bahwa seluruh Gereja diutus dan ditugaskan Kristus untuk menjalankan tugas perutusan. Tugas perutusan Kristus sebagai nabi, imam, dan raja dilanjutkan oleh Gereja, bukan oleh satu golongan saja, misalnya hanya oleh kaum tertahbis, atau oleh golongan biarawan-biarawati saja, melainkan oleh seluruh kaum beriman Kristen, jadi termasuk kaum awam.

Menurut konsili, panggilan pertama dan utama yang kita terima dari Allah melalui sakramen baptis ialah panggilan menjadi anggota Gereja, dan sejauh sebagai anggota Gereja mendapat tugas yang sama pula dari Kristus yakni sebagai imam, nabi dan raja. Oleh permandian kita semua, baik itu imam, suster, bruder, frater, dan awam, memiliki martabat yang sama sebagai anggota Umat Allah. Baru atas dasar kesamaan yang fundamental itu terjadilah pembagian dalam cara perwujudan tugas perutusan Gereja. Karena itu konsili tidak menghapus perbedaan antara ketiga golongan kaum beriman itu. Perbedaan antara imam dan awam adalah perbedaan fungsional, yakni imam berfungsi mewakili Kristus memimpin Gereja sedangkan awam tidak. Demikian juga antara awam dan biarawan-biarawati ada perbedaan yang disebut perbedaan karismatis, dimana biarawan-biarawati memiliki karisma untuk memberikan kesaksian unggul dan luhur. ${ }^{3}$

\section{Awam dan Hirarki}

Hirarki adalah uskup, imam, dan diakon. Konsili Vatikan II mengajarkan bahwa sejak awal Gereja didirikan sudah ada hirarki. Namun itu tidak berarti bahwa Gereja sama dengan hirarki itu, tetapi itu berarti bahwa hirarki termasuk unsur konstitutif Gereja. Tanpa hirarki tidak ada Gereja. Tetapi fungsi hirarki dengan kuasa suci (sacra potestas) dan otoritas (auctoritas) yang dimilikinya bukan untuk menguasai melainkan untuk melayani. Dibandingkan dengan awam, hirarki adalah golongan fungsional di dalam Gereja yang harus ada demi kelangsungan hidup Gereja, karena fungsinya memperagakan kepemimpinan Kristus (in persona Christi). Hirarki adalah pejabat yang memungkinkan hidup Gereja bagi semua anggota Gereja. Sedangkan tugas untuk

3 Georg Kircberger, Allah Menggugat. Sebuah Dogmatik Kristiani, Maumere: Ledalero, 2007, hlm. 615-625. 
mengembangkan hidup Gereja bukan hanya tugas hirarki melainkan tugas semua orang Kristen.

Dengan demikian, kita tidak boleh memandang hirarki sebagai golongan tersendiri yang seakan-akan ditempatkan di atas umat melainkan sebagai bagian dari Umat Allah. Sampai sekarang masih ada kaum beriman memahami Umat Allah itu adalah awam saja. Padahal istilah Umat Allah dari Vatikan II mencakupi awam, kaum biarawan, dan kaum tertahbis. Jadi, imam dan uskup itu juga Umat Allah. Kaum hirarki itu termasuk anggota Umat Allah dan mereka baru terbedakan dari anggota Umat Allah yang awam karena kaum hirarki memiliki fungsi khusus di dalam Gereja yakni memimpin Gereja.

Akan tetapi, pembaruan ini yakni dari Gereja Hirarki menjadi Gereja Umat Allah tujuannya bukan untuk menghapuskan peran hirarki di dalam Gereja untuk kemudian digantikan oleh umat. Tujuan konsili adalah bahwa kalau sebelum Vatikan II awam pasif saja menerima pelayanan dari hirarki, maka konsili mau agar awam juga aktif di dalam Gereja, aktif mengambil bagian dalam menjalankan perutusan Gereja.
Konsili memandang kaum awam sebagai anggota Umat Allah sangat menentukan Gereja, karena merekalah yang mengenal dunia. Sejak itu hubungan antara awam dan hirarki tidak lagi digambarkan sebagai hubungan ketaatan saja dari pihak awam, tetapi lebih menurut corak kerjasama. Akan tetapi model hubungan kerjasama ini tetap dengan pemahaman bahwa yang memimpin Gereja tetap kaum hirarki, karena hanya kaum hirarki, oleh tahbisan sucinya, menjadi wakil Kristus, untuk memimpin Gereja. ${ }^{4}$

\section{Awam dan Fungsi Duniawi}

Menurut konsili ciri khas dan tugas khusus kaum awam dalam kehidupan Gereja adalah tugas di tengah dunia dan masyarakat. Tugas awam adalah menguduskan dunia, meresapi pelbagai bidang urusan duniawi dengan semangat Kristus, agar semangat dan cara hidup Kristus mengolah seluruh dunia bagaikan ragi, garam, dan terang, sehingga Kerajaan Allah bisa hadir di tengah masyarakat. Pernyataan kunci di sini adalah "berdasarkan panggilan khasnya awam bertugas mencari

\footnotetext{
${ }^{4}$ Ibid., hlm. 621-622.
} 
Kerajaan Allah dengan mengusahakan hal-hal duniawi dan mengaturnya sesuai dengan kehendak Allah". 5

Konsili juga mengajarkan bahwa Gereja tidak berada untuk dirinya sendiri tetapi untuk pelayanan terhadap dunia dan masyarakat. Kalau Gereja hadir untuk melayani masyarakat dan dunia, maka para awam mempunyai suatu tugas yang sangat essensial bagi Gereja. Para awam melalui hidup dan sesuai bidang tugas masing-masing dalam masyarakat menghadirkan Roh dan semangat Kristus yang diberikan kepada Gereja itu di tengah masyarakat. Itu artinya, tugas perutusan awam dijalankan tidak dengan meninggalkan tugas pekerjaan mereka, melainkan dalam menjalankan tugas pekerjaan mereka seturut semangat Kristus, itulah tugas perutusan mereka.

Namun konsili tetap mengingatkan agar kaum beriman tidak menyederhanakan pembagian perutusan gerejani, yakni seakan-akan kaum tertahbis dan kaum biarawan-biarawati melakukan perutusan di dalam Gereja (ad intra) atau pembangunan intern Gereja, sedangkan kaum awam

\footnotetext{
${ }^{5}$ Konstitusi Dogmatis tentang Gereja, Lumen Gentium
} 31. melakukan perutusan di luar Gereja (ad extra), yakni urusan duniawi. Yang utama bukan pembagian yang tegas antara awam dan kaum tertahbis, karena konsili berpikir organik yang dirumuskan dengan kerangka Gereja Umat Allah. Menurut konsili, yang paling utama adalah bahwa seluruh angggota Umat Allah itu dipanggil untuk sungguh-sungguh menjadi orang Kristen, yaitu mereka menjadi tanda nyata tentang maksud dan rencana Allah di tengah dunia dan masyarakat. Mereka harus menjadi sakramen bagi dunia, bagi masyarakat, bagi orang lain, agar mereka semua itu juga bisa mengenal cinta Allah dan menjadi manusia baru oleh Roh.

Jika demikian kerangka teologinya maka kaum awam memiliki fungsi misioner yang lebih kuat dan lebih nyata. Karena, kaum awam menjalankan pelbagai profesi duniawi di pelbagai bidang, yang tidak dimasuki oleh kaum tertahbis dan kaum biarawan-biarawati. Jadi kaum awamlah yang sesungguhnya secara nyata dan luas meresapkan semangat Kristus itu ke dalam pelbagai bidang dan urusan duniawi. Sedangkan peran para gembala dan biarawanbiarawati agak terbatas karena lebih kuat 
terlibat dalam dan terbatas pada pembangunan intern Gereja. Tetapi, seperti ditegaskan di atas bahwa kita tidak boleh terjebak dalam pemikiran untuk memisahkan dalam tugas. Karena bagi konsili tidak ada pemisahan dalam tugas melainkan hanya ada penekanan.

Hal ini akan menjadi jelas kalau kita mengaitkan perutusan Gereja dengan satu faham kunci Vatikan II yakni Gereja sebagai communio. ${ }^{6}$ Maka, kaum awam di sini adalah pilar utama dari komunio iman. Tetapi komunio iman itu bukan bersifat liturgis belaka, melainkan justru karena sifatnya sebagai awam maka komunio dibangun dalam aspek duniawinya juga. Kalau keterlibatan awam dalam Gereja hanya berkisar pada pelayanan altar dan mimbar maka justru aspek keawaman tidak langsung terkena. Para awam semakin menjadi orang Kristen justru dengan mengembangkan segi komunio itu dalam hubungannya dengan dunianya sendiri. ${ }^{7}$

${ }^{6}$ Penjelasan teologis tentang Gereja Communio dan hubungannya dengan Gereja Umat Allah serta implikasinya bagi Gereja di Indonesia, baca: Rm. Martin Chen, Pr, "Eklesiologi Communio Konsili Vatikan II", dalam Spektrum. Dokumentasi dan Informasi KWI, No. 4 Tahun XLI, 2013, hlm. 35-61.

7 Stephanus Gitowiratmo, Pr, "Gereja Kaum Awam sebagai Proses Perwujudan Iman”, dalam Teologi dan Spiritualitas, Orientasi Baru, Pustaka Filsafat dan Teologi, No 8, Yogyakarta: Kanisius, 1994, hlm. 151.

\section{Awam dan Perutusan Diakonia}

\section{Awam dan Wujud Iman yang Sekular}

Gaudium et Spes, konstitusi pastoral tentang Gereja di dunia dewasa ini, dengan sangat jelas berbicara tentang hal-hal yang duniawi ini. Gereja tidak hanya menampilkan diri dalam ibadat (liturgia) dan ajaran (kerygma), tetapi Gereja harus menampilkan wajah manusiawinya yakni Gereja hadir di tengah dunia nyata kehidupan masyarakat manusia dengan segala permasalahannya. Itulah yang kita sebut wujud iman yang sekular. ${ }^{8}$

Wujud iman yang sekular itu menentukan segala aspek kehidupan kaum beriman Kristen. Seorang awam menjalankan perutusan diakonia berarti ia melakukan pelayanan bagi sesama, wujudnya bisa: mengunjungi orang sakit; membantu anak yatim piatu; memberikan sumbangan bagi bencana alam; memberi derma untuk suatu proyek sosial; memperjuangkan undangundang yang adil; membela orang yang tertindas dan teraniaya; membongkar

\footnotetext{
${ }^{8}$ Wujud iman yang sekular dibicarakan oleh Konisli Vatikan II dalam Konstitusi Pastotal tentang Gereja dalam dunia dewasa ini, Gaudium et Spes (1965).
} 
struktur-struktur sosial politik yang korup; dan menjalankan tugas dengan tanggung jawab dan semangat kristiani sebagai guru, dosen, perawat, kontraktor, petani, tukang, sopir, buruh bangunan, pembantu rumah tangga, wartawan, seniman, pegawai negeri di kantor, anggota perlemen, polisi, tentara, hakim, jaksa, bupati, gubernur, dan menteri. Singkatnya, tidak ada satu bidang kehidupan yang sekular pun yang luput dari pelayanan kaum awam dengan semangat kasih kristiani.

Jadi perutusan diakonia bukanlah sebuah misi yang dijalankan dengan meninggalkan pekerjaan dan kehidupan nyata sehari-hari kaum beriman melainkan kaum beriman menjalankan tugas dan pekerjaan sehari-hari dengan semangat tanggung jawab kristiani. Sebagai sakramen keselamatan Gereja didirikan oleh Kristus sebagai tanda dan sarana yang memperbaiki situasi dunia dan masyarakat sehingga semua orang bisa hidup sejahtera dan bahagia seturut kehendak Tuhan. Hanya dengan keterlibatan dalam masalah-masalah hidup sehari-hari, kaum beriman awam dapat menjadi saksi iman yang nyata. Atau dengan kata lain, hanya dengan keterlibatan dalam dunia kehidupan masyarakat dengan segala ciri dan tantangannya, iman kaum awam menjadi nyata.

Manakala awam Katolik menjalankan imannya hanya dengan kusuk berdoa, entah doa pribadi ataupun doa kelompok, menghadiri Misa Minggu di Gereja dan mendengarkan pewartaan di sana, berkatekese, maka orang itu baru melakukan pengungkapan iman dan belum sampai kepada pengamalan iman. Namun dengan perutusan diakonia, yaitu perutusan melakukan pelayanan dalam dunia dan masyarakat dengan semangat kasih kristiani, barulah iman itu diamalkan dan menjadi nyata. Iman Gereja, iman kaum awam, baru mendapat wujud nyata ketika orang Katolik itu meninggalkan ruang Gereja dan lalu menggemakan jawaban mereka atas panggilan Allah di tengah-tengah tanggung jawab setiap hari.

Poin penting di sini adalah bahwa iman hanya memperoleh wujud dan kenyataan di dalam keterlibatan dan tanggung jawab orang beriman berhadapan dengan soal-soal hidup aktual. Tentu ada banyak persoalan hidup di tengah masyarakat saat ini di 
bidang politik, ekonomi, hukum, Ketidakadilan bisa bersifat pendidikan, dan lingkungan hidup. perseorangan namun juga bisa bersifat Berikut ini saya hanya mengangkat dua struktural. Ketidakadilan perseorangan persoalan sosial saat ini, yang menurut tidak rumit, karena pengertiannya cukup saya sudah menunjukkan adanya jelas, yaitu seseorang bertindak tidak pemisahan antara iman dan hidup, yaitu ketidakadilan dan korupsi.

\section{Awam, Ketidakadilan, dan Ateisme} Praktis

Sejak Rerum Novarum, Ajaran Sosial Gereja pertama, sampai dengan sekarang, terutama Konsili Vatikan II melalui Konstitusi Pastoral Gaudium et Spes, Gereja sungguh sadar bahwa dunia tempat kita tinggal ini dengan segala masalah dan harapannya merupakan tempat dimana Allah sungguh hadir dan bersabda kepada kita, walaupun masih secara terselubung. Sejak itu Gereja mulai sadar bahwa zaman dan masyarakatnya mengandung tanda-tanda zaman, yang harus diartikan dan ditanggapi dengan terang Injil. Dan salah satu tanda-tanda zaman yang sangat jelas dan menantang kita saat ini adalah ketidakadilan yang merusak wajah hidup bersama sebagai hidup yang penuh cinta kasih. adil terhadap seseorang lainnya. Ketidakadilan jenis ini umumnya sejak lama dikecam oleh Gereja. Namun ketidakadilan struktural, atau yang sekarang disebut dengan nama ketidakadilan sosial, tidaklah mudah diamati dan dinilai karena ketidakadilan jenis ini tidak secara langsung disebabkan oleh sikap perseorangan yang tidak adil. Ketidakadilan sosial atau ketidakadilan struktural adalah ketidakadilan yang meresapi struktur dan lembaga-lembaga sosial politik, ekonomi, dan hukum, serta cara berjalannya dan menjelma di dalamnya. Tetapi yang jelas ketidakadilan ini pun dibuat oleh manusia, hanya saja tidak dilakukan secara perseorangan melainkan secara bersama-sama lewat tindakan politis, ekonomis, dan sosial budaya.

Lalu, apa urusan Gereja dengan ketidakadilan, bukankah itu masalah sosial politik yang harus diurus oleh institusi politik negara. Benar bahwa 
ketidakadilan sosial adalah masalah politik. Namun bagi orang beriman kristiani ketidakadilan sosial itu juga masalah iman. Seringkali kurang disadari bahwa antara pewartaan Injil dan penegakan keadilan terdapat suatu hubungan erat dan mendalam. Padahal pewartaan Injil itu harus dinyatakan dan diwujudkan dalam perjuangan demi keadilan, dan sebaliknya perjuangan keadilan itu membutuhkan terang Inil.

Di mata Gereja usaha menghapus ketidakadilan itu adalah perintah Injil, karena ketidakadilan itu mengingkari keluhuruan martabat dan hak-hak manusia sebagai imago Dei (gambar Allah) dan saudara-saudari Kristus. Itulah sebabnya bagi Gereja, pewartaan Injil tentang penebusan dan pembebasan manusia, terutama mereka yang paling menderita, yang paling tertindas, yang paling miskin dan tersingkir, hanya bisa dipercayai dan diterima, manakala mereka yang menderita itu didatangi dan disapa di dalam kondisi yang mereka alami. Kalau pewartaan Gereja tidak disertai oleh keterlibatan nyata, maka Injil akan dianggap sebagai dunia katakata saja dan bukan dunia kenyataan.
Paus Benediktus XVI, dalam Deus Caritas est, artikel 29, berkata: “Tugas langsung menghasilkan tatanan adil dalam masyarakat, merupakan tugas kaum beriman awam. Sebagai warga negara mereka dipanggil untuk berpartisipasi secara pribadi dalam hidup publik. Maka mereka tak dapat lepas tangan, mereka harus melibatkan diri dalam banyak dan pelbagai prakarsa di bidang ekonomi, sosial, legislatif, eksekutif dan kultural, yang mengabdi kepentingan umum secara organis dan institusional." Jadi adalah tanggung jawab orang awam Katolik untuk memperjuangkan keadilan. Perintah menegakkan keadilan tidak politis melainkan gerejani, karena di mata Gereja setiap bentuk ketidakadilan di bidang ekonomi, politik, dan hukum, bertentangan dengan semangat Injil dan tujuan Kerajaan Allah

Karena itu orang Kristen yang melakukan ketidakadilan atau pun membiarkan ketidakadilan berlangsung, sesungguhnya orang itu telah mengingkari Allah dalam hidupnya. Maka ketidakadilan sebenarnya berupa 
ateisme praktis. ${ }^{9}$ Disebut ateisme praktis karena orang itu mengingkari Allah dalam hidupnya bukan dengan perkataan atau argumentasi rasional seperti yang dilakukan oleh ateisme teoretis melainkan dengan tindakan nyata. Bertindak secara tidak adil atau menunjang ketidakadilan struktural sama dengan bertindak seakan-akan tidak ada Allah. Dan ateisme praktis itu, terutama kalau dilakukan oleh orang mengakui Kristen, bisa lebih berbahaya daripada ateisme teoretis yang menyangkal eksistensi Allah dengan kata-kata. ${ }^{10}$

Gaudium et Spes 43, mengingatkan kita bahwa dalam hidup orang beriman Kristen tidak ada pemisahan antara yang ilahi dan yang duniawi, dan iman yang sungguh-sungguh nyata adalah iman di tengah dunia dan masyarakat. "Oleh karena itu janganlah secara salah

\footnotetext{
9 J. Mueller, SJ, "Pewartaan Injil dan Penegakan Keadilan. Tugas Perutusan Gereja di Tengah Masalahmasalah Sosial, dalam Eduard R. Dopo (ed.), Keprihatinan Sosial Gereja, Yogyakarta: Kanisius, 1992, hlm.50. Bdk juga, J.B. Banawiratma, SJ \& J. Mueller, SJ, Berteologi Sosial Lintas Ilmu. Kemiskinan sebagai Tantangan Hidup Beriman, Yogyakarta: Kanisius, 1993, hlm. 167-168.

10 Bdk. Gaudium et Spes 19: “...banyak di antara orang-orang zaman sekarang sama sekali tidak menyadari hubungan kehidupan yang mesra dengan Allah itu atau tegas tandas menolaknya, sehingga sekarang ini ateisme memang termasuk kenyataan yang paling gawat..."; juga, Paus Paulus VI, dalam Himbau Apostolik Evangellii Nuntiandi (1975), khususnya artikel 55, berbicara tentang ancaman ateisme.
}

kegiatan kejuruan dan sosial di satu pihak dipertentangkan terhadap hidup keagamaan di pihak lain”. Gaudium et Spes 43, menegaskan lebih lanjut: "Dengan mengabaikan tugas kewajibannya di dunia ini orang Kristen melalaikan tugas-kewajibannya terhadap sesama, bahkan mengabaikan Allah sendiri, dan membahayakan keselamatan kekalnya".

Kemudian Gaudium et Spes 21, berbicara tentang sikap Gereja terhadap ateisme atau tentang cara menghadapi ateisme. Menurut konsili caranya adalah "iman itu harus menampakkan kesuburannya dengan merasuki seluruh hidup kaum beriman, juga hidup mereka yang profan, dan dengan menggerakkan mereka untuk menegakkan keadilan dan mengamalkan cinta kasih, terutama terhadap kaum miskin”.

\section{Awam, Korupsi, dan Ibadat yang Munafik}

Korupsi adalah kosa kata relatif baru di dalam Ajaran Sosial Gereja. Dari segi isi perbuatan tradisi moral Kristiani mengelompokkan korupsi itu pada pelanggaran moral yang disebut pencurian yang kemudian menuntut 
restitusi. Di dalam Konstitusi Pastoral Gaudium et Spes, tentang Tugas Gereja dalam dunia dewasa ini, kita tidak temukan kata itu. Kita baru temukan istilah korupsi di dalam dokumendokumen Gereja, seperti: Sollicitudo Rei Socialis 44; Christifideles Laici 42; Centesimus Annus 48; Misercodiae Vultus 19; dan Evangelii Gaudium 56 dan 189.

Dalam konteks teologi moral mungkin kita bertanya: apa buruknya korupsi itu? Jawabannya adalah bahwa korupsi itu suatu malum, suatu keburukan moral. Keburukan moralnya bukan bahwa uang diselewengkan atau bahwa hak orang lain dirampas, melainkan karena korupsi itu dalam bentuk memeras atau menyuap menjalar dengan cepat, merongrong respek terhadap kewibawaan institusi politik, menyebarkan suasana ketidakpercayaan. Bahkan korupsi dalam bentuk penyuapan, yang sering dianggap tidak apa-apa, hanya bisa terjadi dalam suasana pemerasan dan ikut mempertebal suasana pemerasan. Jadi, jelas korupsi itu dosa. Namun korupsi bukan dosa melawan hak milik yang mudah dipulihkan, melainkan dosa melawan kesetiakawanan dalam lingkungan hidup bersama sebagai suatu masyarakat. Kesetiakawanan yang runtuh itu hampir mustahi dipulihkan. ${ }^{11}$

Di dalam Bulla Misericordiae Vultus 19, Paus Fransiskus menilai korupsi secara moral dan bagaimana korupsi itu bekerja dan menyebar. "Korupsi menghalangi kita memandang masa depan dengan harapan, karena keserakahannya yang kejam merusak rencana orang lemah dan bertindak semena-mena terhadap mereka yang termiskin dari antara kaum miskin." Lalu paus mengemukakan bagaimana korupsi itu bekerja: "Korupsi adalah kejahatan yang melekat pada kegiatan hidup sehari-hari dan menyebar, dengan menyebabkan skandal publik yang berat". Dan akhirnya ia memberikan penilaian moral: "Korupsi adalah tindakan pengerasan hati penuh dosa yang menggantikan Allah dengan ilusi seolah-olah uang adalah bentuk kekuasaan. Korupsi adalah karya kegelapan, yang disuburkan dengan kecurigaan dan intrik".

11 Bernhard Kieser. SJ, Moral Sosial. Keterlibatan Umat dalam Hidup Bernasyarakat, Yogyakarta: Kanisius, 1987, hlm. 109-110. 
Kata-kata Paus Fransiskus ini semakin gila dan mewah. Wanita-wanita hampir sama kritik Nabi Amos dan Nabi di Samaria ikut mendorong pemerasan Yesaya dalam perjanjian Lama. atas orang-orang miskin. Karena itu, Lazimnya dalam Perjanjian Lama harta Amos menyebut mereka sapi-sapi benda dinilai positif yaitu sebagai pemberian Allah. Akan tetapi di dalam Amsal ditemukan peringatan terhadap kelimpahan dan kemewahan. Kerapkali kekayaan menuntun orang kepada rasa tenteram yang palsu dan kepada ateisme praktis. Kelimpahan sebagai hasil dari korupsi itu menimbulkan akibat yang jauh lebih buruk, yakni sikap acuh tak acuh, tuli dan buta terhadap sesama dan Allah. Orang-orang kaya menjadi acuh tak acuh terhadap ketidakadilan di sekitarnya: orang kaya menjadi tuli terhadap seruan rakyat jelata dan menjadi buta terhadap keruntuhan yang mengancam. ${ }^{12}$

Nabi Amos melihat sikap nyonya-nyonya terkemuka di Samaria sebagai salah satu sebab penting terjadinya korupsi dan penindasan: para pemimpin memerlukan semakin banyak uang untuk memenuhi keinginankeinginan isteri-isteri mereka yang

${ }^{12}$ W. van der Weiden, MSF, "Kritik Sosial dari Nabinabi Israel", dalam J.B. Banawiratma, SJ (ed.) Aspekaspek Teologi Sosial, Yogyakarta: Kanisius, 1988, hlm. 55-90. tambun dari Bashan, nyonya-nyonya besar, yang membujuk suami mereka melakukan tindak korupsi. Amos mengecam pejabat yang menyalahgunakan barang yang dipercayakan kepada mereka. ${ }^{13}$

Lalu Amos mengeritik tindakan peribadatan mereka yang telah melakukan pemerasan dan korupsi itu sebagai suatu kemunafikan. Ibadat di kuil-kuil di Betel dan Gilgal, menurut Amos, sebetulnya dipakai oleh pelaku kejahatan korupsi dan pemerasan itu untuk menenangkan suara hati mereka. Ibadat dilakukan hanya untuk mengimbangi kelaliman dan kejahatan pemerasan yang mereka telah lakukan. Amos menilai bahwa itu adalah ibadat yang munafik, seakan-akan manusia dapat menipu Yahwe. Mereka beribadat hanya untuk menenangkan suara hati mereka karena telah melukai hidup sesamanya dan juga melukai hati Allah. Itulah ibadat yang munafik. ${ }^{14}$

\footnotetext{
${ }^{13}$ Ibid., hlm. 65.

${ }^{14}$ Ibid., hlm. 75-79.
} 
Sedangkan Nabi Yesaya mengeritik ketidakadilan sosial yang merajalela dalam masyarakat Yehuda. Yesaya 1:1017 bicara tentang ibadat yang sebetulnya sangat indah dan sempurna, namun itu munafik. Yesaya mengeritik pedas peribadatan yang indah dan penuh persembahan itu karena peribadatan itu dilakukan hanya untuk menyeimbangi ketidakadilan mereka. Itulah sebuah ibadat yang munafik. Suara hati ditenangkan melalui usaha yang berlebihan dalam hal ibadat. Mereka mengira bahwa ibadat yang bagus pada hari Sabat dapat menutup dan menghapus ketidakadilan yang telah dilakukan pada hari-hari biasa. Tetapi Tuhan mempunyai ukuran lain: munafiklah setiap ibadat yang dilakukan orang yang tidak mau mengindahkan dimensi horizontal perjanjian Sinai. ${ }^{15}$

Teologi moral Katolik menilai tindakan ibadat seperti yang dikritik oleh Nabi Amos dan Nabi Yesaya itu adalah suatu "kebaktian palsu kepada Allah yang benar". ${ }^{16}$ Kebaktian itu palsu

${ }^{15}$ Al. Purwa Hadiwardoyo, MSF, "Pewartaan Injil dan Keadilan", dalam JB Banawiratma, SJ, Gereja dan Masyarakat, Yogyakarta: Kanisius, 1986, hlm.62-67.

16 Karl Heinz Pesche SVD, Etika Kristiani Jili II Kewajiban Moral dalam Hidup Keagamaan (terj. karena kebaktian itu menggunakan sarana-sarana yang tidak pantas. Tidak pantas bagi Allah adalah rupa-rupa sarana dan tindakan yang dilakukan dengan tujuan ibadat, yang bukan merupakan ungkapan sejati hati manusia kepada Allah.

Ritualisme sangat dicela oleh Amos dan Yesaya. Gereja juga sama, mengecam perilaku ibadat yang munafik, mengecam kesucian ritualistik, karena orang yang beribadat itu membayangkan Allah sebagai seorang raja surgawi yang menuntut haknya dari manusia dalam bentuk korban besar dan rupa-rupa tindakan peribadatan Persembahan besar dan mewah itu dipandang semacam pajak yang harus dibayarkan kepada Allah. Begitu pajak itu dilunasi maka mereka merasa telah bebas dari kejahatan yang telah mereka lakukan terhadap sesama, malah merasa berhak untuk melakukan lagi kejahatan yang sama karena pajak Allah sudah dibayarkan. Tentu suatu ironi iman, melakukan korupsi yang merugikan kehidupan bersama, lalu kekayaan hasil

Alex Armanjaya, Yosef M. Florisan, G. Kirchberger), Maumere: Ledalero, 2003, hlm. 128-130. 
korupsi itu diambil untuk dijadikan persembahan bagi Allah.

\section{Wujud Tanggung Jawab Awam}

Apa tugas dan tanggung jawab kaum awam terhadap kedua masalah sosial itu? Jawabannya adalah mereka menerapkan Sabda Allah pada kehidupan manusia dan masyarakat demi terciptanya suatu kondisi masyarakat yang manusiawi. Sejauh ini, berdasarkan inspirasi Injil dan prinsip-prinsip pembimbing Ajaran Sosial Gereja itu, kita mengenal kurang lebih ada empat tindakan ${ }^{17}$ nyata yang harus dilakukan oleh kaum awam beriman untuk melayani masyarakat, yaitu: tindakan moral, tindakan karitatif, tindakan profetis, dan tindakan politis.

\footnotetext{
${ }^{17}$ Sebenarnya ada 5 (lima) tindakan gerejani dalam menanggapi kondisi sosial manusia, yakni ditambah "tindakan solidaritas" yang dikemukakan oleh Paus Yohanes Paulus II di dalam Ensiklik Sollicitudo Rei Socialis, terutama dalam menghadapi realitas penderitaan orang miskin. Di dalam ensiklik ini paus memasukkan tindakan solidaritas ke dalam dimensi politik. Solidaritas adalah "tekad kuat dan tetap untuk memperjuangkan kesejahteraan umum" (artikel 38). Meski istilah solidaritas tidak berasal dari bahasa Gereja, namun, sebagaimana dijelaskan oleh paus, solidaritas adalah keutamaan khas kristiani (artikel 40).
}

\section{Wujud Iman dalam "Tindakan Moral"}

Bicara tindakan moral adalah bicara tentang perubahan kondisi dan sikap tobat. Karena ketidakadilan dan korupsi sebagai tindakan pelanggaran yang terjadi tidak hanya dalam lingkaran kelemahan pribadi melainkan terutama dalam lingkungan sosial, maka pertobatan juga bersifat personal dan sosial. Tanggung jawab iman atas tindakan pelanggaran pribadi adalah pertobatan diri sang pelaku dan tanggung jawab iman atas dosa sosial adalah pertobatan sosial.

Tetapi apa itu dosa sosial dan pertobatan sosial. Amanat Apostolik Reconciliatio et Paenintentia ${ }^{18}$, artikel 16, menerangkan dosa sosial demikian: Dosa sosial adalah dosa-dosa yang melawan sesama, seperti dosa-dosa melawan keadilan yang dilakukan oleh individu melawan komunitas maupun oleh komunitas melawan individu. Dosa

\footnotetext{
${ }^{18}$ Amanat Apostolik Reconciliatio et Paenitentia, dari Paus Yohanes Paulus II, dikeluarkan pada 2 Desember 1984. Paus berbicara tentang perwujudan tanggung jawab sosial kaum beriman Kristen, baik secara pribadi maupun secara struktural-institusional, berhadapan dengan realitas ketidakadilan sosial. Paus akhirnya berbicara tentang struktur pertobatan atau struktur rahmat: kehidupan manusia berada dalam ketegangan antara hukum dosa dan hukum rahmat dan panggilan Gereja untuk menghantar manusia kepada hukum rahmat.
} 
sosial itu berlawanan dengan rencana Allah berkaitan dengan struktur-struktur sosial. Dalam arti ini dosa tidak lagi dimengerti seperti dosa personal yang menyangkut pilihan dan putusan bebas seorang individu. Di sini dosa dipakai secara analog karena dosa sosial tidak menyangkut putusan bebas dan tanggung jawab seorang pelaku, melainkan menyangkut kondisi sosial dan kondisi sosial itu berada di luar kekuatan pilihan dan keputusan bebas seorang manusia. Jadi, dosa sosial tertanam dalam struktur-struktur kehidupan masyarakat.

Menurut Paus Yohanes Paulus II, sebagaimana ditulisnya di dalam Sollicitudo Rei Socialis 36, strukturstruktur dosa ini "berakar di dalam dosa pribadi, dan dengan demikian selalu dikaitkan dengan tindakan-tindakan konkret individu-individu yang menciptakan struktur-struktur itu, memperkuat dan membuat strukturstruktur itu sulit dihilangkan. Dengan demikian struktur-struktur itu bertumbuh menjadi lebih kuat, meluas dan menjadi sumber dosa-dosa lain, dan demikian mempengaruhi tingkah laku orangorang". Di sini ada suatu lingkaran setan yang saling mempengaruhi: Dosa sosial menciptakan ruang yang membuat dosa pribadi dipermudah dan dianggap wajar, dan kemudian dosa pribadi itu justru kembali memperkuat struktur dosa atau dosa sosial.

Lalu, mana yang sulit untuk diatasi, dosa pribadi atau dosa sosial? Jawabannya, bukan dosa pribadi melainkan dosa sosial. Mengapa? Karena, di satu pihak semua tindakan kita sebagai pribadi tidak luput dari kondisi ketidakadilan sosial itu sehingga tingkah laku perserorang masing-masing kita selalu bagaimanapun dalam bahaya meleset dari sikap adil. Di pihak lain, struktur dan lembaga sosial tersusun dan terarahkan sedemikian rupa sehingga tindakan kita sebagai pribadi kerapkali tanpa kita sadari justru bisa menunjang ketidakadilan, meskipun kehendak pribadi kita sungguh berniat baik.

Dalam hal ini perlu kita sadari betul bahwa struktur-struktur tersebut merupakan kenyataan konkret, yang meskipun semula berakar pada dosa pribadi, namun pada gilirannya mempunyai kekuatan sendiri. Artinya, pada gilirannya kekuatan-kekuatan dosa yang terwujud dalam struktur sosial 
tersebut menjadi sulit dibasmi, juga meskipun individu-individu

menghendakinya. Dalam hal ini antara dosa pribadi dan struktur dosa terdapat hubungan timbal balik, dimana dosa pribadi memperkuat struktur dosa dan sebaliknya struktur sosial yang tidak beres itu menyeret dosa pribadi.

Pertanyaan kita sekarang: apakah perutusan diakonia awam, dalam wujud tindakan moral ini, berfokus pada pertobatan pribadi atau pertobatan sosial? Dari uraian di atas jawaban jelas bahwa karena dosa pribadi dan dosa sosial saling mempengaruhi maka pertobatan pribadi dan pertobatan sosial diperlukan agar perubahan struktur demi kemajuan masyarakat dapat terjadi. Kemajuan masyarakat berarti kemajuan manusia sebagai pribadi yang secitra dengan Allah. Pertobatan pribadi mempunyai pengaruh sosial dan dapat menggerakkan pertobatan sosial atau perubahan kondisi masyarakat. Lalu secara bersama pertobatan pribadi dan pertobatan sosial dilakukan maka lahirlah gerakan bersama yang bersifat struktural untuk memperbaiki kondisi masyarakat menjadi lebih manusiawi.

\section{Wujud Iman dalam "Tindakan Karitatif"}

Salah satu wujud dari cinta kasih adalah tindakan karya amal bagi sesama yang menderita. Karya amal adalah salah satu bentuk perwujudan cinta kasih yang paling tua. Paus Benediktus menulis di dalam Deus Caritas est, art. 29: "Organiasai karitatif Gereja merupakan opus proprium, karya khas. Gereja tak dapat dibebaskan dari pelayanan kasih sebagai kegiatan bersama teratur kaum beriman, dan di lain pihak tak pernah ada keadaan di mana pelayanan kasih individual orang kristiani tak diperlukan, karena manusia tak hanya membutuhkan keadilan, melainkan juga akan selalu membutuhkan kasih". Di sini paus membicarakan dua hal: pertama, tentang dua wujud pelaksanaan karya amal yakni secara individual dan secara bersama melalui lembaga yang sekarang kita kenal Caritas; kedua, pelaksanaan karya amal ada hubungan dengan kewajiban keadilan.

Gereja mendorong seluruh kaum beriman Kristen untuk menjalankan perintah Injil, "kamu telah memperolehnya dengan cuma-cuma, karena itu berikanlah pula dengan cuma- 
cuma" (Mat 10:8). Karena itu setiap orang Kristen harus membantu sesamanya di dalam berbagai kebutuhannya dan memenuhi masyarakat manusia dengan karya-karya belas kasih baik di bidang jasmani maupun rohani tanpa batas. Dari semua karya belas kasih itu, Gereja mengajarkan bahwa memberi derma kepada orang miskin adalah salah satu dari kesaksian utama cinta kasih persaudaraan. Akan tetapi, Gereja masih menambahkan bahwa memberi bantuan kepada orang miskin itu memang kesaksian utama namun itu juga merupakan perbuatan keadilan yang berkenan kepada Allah.

Meski karya amal adalah opus proprium pewartaan Gereja namun tidak tanpa kelemahan. Karya amal mudah membutakan mata kaum beriman bahwa realitas kemiskinan adalah bagian realitas hidup masyarakat. Orang menjadi miskin dan menderita tentu ada sebab individualnya, misalnya, malas dan bodoh, namun kemiskinan itu juga disebabkan oleh struktur sosial, politik, ekonomi, dan budaya yang tidak adil, jadi ketidakadilan sosial. Karena itu, kaum beriman dan terutama dalam hal ini kaum awam, perlu sungguh sadar bahwa memberi bantuan kepada orang miskin adalah perwujudan iman, namun bukan hanya terbatas di situ. Perwujudan iman baru sempurna manakala kaum beriman berusaha membongkar struktur sosial yang menyebabkan segelintir orang berkelimpahan dan sebagian besar lainnya menderita miskin. Perintah membongkar ketidakadilan inilah bentuk perwujudan iman di tengah masyarakat yang paling jelas dan paling dituntut oleh Gereja.

Gereja menghendaki agar perbuatan karya amal tidak boleh mengabaikan kewajiban kaum beriman iman untuk menghapus ketidakadilan dan korupsi. Seorang kaya memberikan bantuan kepada orang miskin atau sumbangan kepada lembaga yang mengurus orang miskin, patut kita puji. Akan tetapi mata kita kiranya tidak boleh tersilau oleh perbuatan baik yang besar itu. Karena, apakah kekayaan atau kelimpahan itu diperoleh karena usaha dan kerja keras menurut cara yang wajar secara moral dan hukum, ataukah menjadi kaya karena pandai memanfaatkan strukturstruktur masyarakat yang korup dan norma hukum yang tidak adil sehingga 
memungkinkan hanya segelintir orang memperoleh secara berkelimpahan dan sebagian besar lainnya hanya mendapat sedikit bahkan tidak mendapatkan apaapa.

Berikut ini, mari kita perhatikan Ajaran Sosial Gereja tentang karya amal dan karya keadilan. Paus Paulus VI dalam Populorum Progressio ${ }^{19} 23$ menulis: "Siapa pun tahu, bahwa para Bapa Gereja mencanangkan tugas kaum kaya terhadap kaum miskin dengan jelas sekali. Berkata St. Ambrosius: Apa yang kamu milik, tidak kamu hadiahkan kepada orang miskin, tetapi kamu mengembalikan miliknya kepadanya". Jadi, sejak dulu Gereja melihat bahwa kelimpahan orang kaya, entah karena kekuasaan ekonomi atau karena kekuasaan politik, dicurigai sebagai buah dari ketidakberesan kondisi sosial, seperti ketidakadilan dan korupsi. Dalam nada yang sama, dalam Regula Pastoralis, St. Gregorius Agung,

${ }^{19}$ Populorum Progressio adalah ensiklik yang ditulis oleh Paus Paulus VI dua tahun setelah Konsili Vatikan II, yaitu pada tahun 1967. Ensiklik ini ditulis oleh paus setelah perjalanannya ke Amerika Latin dan Afrika, juga ke Palestina dan India, dimana beliau menyaksikan sendiri kemiskinan dan kemelaratan orang. Pengalaman itu mendorong paus untuk menyerukan kepada seluruh dunia agar bersama-sama ikut membantu pembangunan bangsa-bangsa yang menderita miskin itu. menulis: "Kalau kita memperhatikan kebutuhan-kebutuhan dari orang-orang yang berkekurangan, maka kita memberi apa yang menjadi hak mereka, bukan hak kita. Alih-alih sekadar melakukan karya-karya belas kasih, kita sebenarnya membayar utang keadilan". ${ }^{20}$

St. Ambrosius menggunakan kata "mengembalikan" sedangkan St. Gregorius Agung menggunakan kata "membayar utang keadilan". Sudah semakin jelas bahwa tindakan karya amal adalah baik dan harus dilakukan, namun tidak hanya sampai di situ. Yang patut kita lakukan sebagai kaum beriman adalah membangun masyarakat yang adil dan bebas dari korupsi. Bayangkan saja, seorang yang menjadi kaya karena hasil korupsi atau hasil perbuatan tidak adil di kantor atau di dunia bisnis dalam bentuk penyuapan atau pemerasan, lalu orang itu memberikan bantuan kepada orang miskin. Karena itu, konsili dengan tegas menganjurkan agar kewajiban keadilan dilaksanakan secara benar, mengingat bahwa "apa yang harus diserahkan berdasarkan keadilan, jangan diberikan sebagai hadiah cinta kasih".

${ }^{20}$ Paus Fransikus mengutip St. Gregorius Agung di dalam Bulla Misericordiae Vultus (Wajah Kerahiman), 11 April 2015. 
Sedangkan Paus Fransiskus berkaitan dengan ajaran mewujudkan cinta kasih dengan karya amal dan hubungannya dengan kewajiban keadilan mengutip Santo Yohanes Chrystotumus. Paus menulis di dalam Evangilii Gaudium 57: “... saya mendorong para ahli keuangan dan para pemimpin politik untuk merenungkan kata-kata sebuah kebijakan kuno: Tidak berbagi kekayaan dengan kaum papa adalah mencuri dari mereka dan mengambil mata pencaharian mereka. Bukan harta benda kita sendiri yang kita genggam, melainkan mereka”.

Dari pandangan Bapa Gereja yang dikutip oleh para paus dalam Ajaran Sosial Gereja itu kita menemukan bahwa karya amal itu adalah karya khas Gereja sejak Gereja ada. Setiap kaum beriman wajib dipanggil untuk menjalankan karya amal bagi sesama yang menderita dengan memberikan sumbangan. Akan tetapi Gereja dengan tegas mengajarkan pula bahwa tindakan karya amal berapa pun besarnya sumbangan itu sama sekali tidak bisa menggantikan kewajiban keadilan. Itu artinya, sebagai pengikut Kristus kita dipanggil untuk berkarya amal, namun tindakan karitatif itu tidak menggantikan kewajiban moral sosial kita untuk menjalankan keadilan. Jika tidak, ironi iman pun muncul: menjadi kaya dengan cara memeras, merampok, dan korupsi, lalu dengan uang itu kita memberikan bantuan bagi orang miskin dan menyumbang Gereja.

\section{Wujud Iman dalam "Tindakan} Profetis"

Tindakan mengeritik atau membongkar kebobrokan masyarakat disebut profetis karena awal mulanya tindakan ini dilakukan oleh para nabi (propheta). Tuhan angkat bicara melalui mulut para nabi untuk melawan ketidakadilan dalam pelbagai bidang saat itu, yaitu bidang peradilan, bidang politik, dan bidang ekonomi.

Gereja dipanggil untuk hal yang sama. Gereja dipanggil untuk bertindak menghapus kemiskinan dan membongkar struktur-struktur kehidupan masyarakat yang tidak adil. Dalam arti inilah perutusan Gereja ke tengah dunia dan masyarakat menjadi tidak semata rohani melainkan berdimensi politis, dimana dimensi politis itu sangat beresiko karena dengan 
sendirinya perutusan itu menyentuh dan menantang struktur-struktur kekuasan dalam masyarakat. Akan tetapi, keyakinan Gereja, makin seseorang bertobat dari dosa dan hatinya terbakar oleh cinta Kristus, maka orang itu akan makin melibatkan dirinya terhadap sesama yang menderita. Ia tanpa takut akan membongkar segala struktur yang menyebabkan sesama saudaranya menderita.

Ciri khas tindakan profetis adalah bahwa Roh Allah mendukung Gereja untuk menggugat situasi yang tidak beres dalam masyarakat agar sesuai dengan kehendak Allah. Kondisi masyarakat harus sekian dibuat sehingga memungkinkan manusia yang adalah citra Allah dapat hidup dan mengembangkan dirinya. Akan tetapi, tugas profetis Gereja bukanlah tugas para hirarki sendiri yaitu untuk berbicara di dalam pelbagai forum terutama mimbar pewartaan di Gereja untuk mengeritik ketidakadilan sosial yang ada. Tugas profetis Gereja adalah tugas semua anggota Gereja, imam, awam dan religius. Karena itu, kelirulah kalau kita membuat pemisahan, tindakan profetis Gereja itu tugas kaum tertahbis dan tindakan politis itulah tugas kaum awam. Tindakan profetis juga tindakan awam dan tindakan politis juga tindakan kaum tertahbis.

Akan tetapi, dengan tindakan profetis ini tidak berarti Gereja memaklumkan kebijakan-kebijakan konkret untuk menghapus korupsi dan ketidakadilan dalam bidang ekonomi, sosial, hukum dan politik, karena Gereja tidak memiliki kompetensi dan keahlian untuk itu. Namun itu tidak berarti bahwa Gereja berbicara secara abstrak saja. Ada situasi tertentu dimana Gereja didesak oleh Roh Allah untuk mengambil sikap, untuk bicara secara terbuka terhadap sebuah tantangan yang dihadapi oleh masyarakat. Begitu, misalnya, Paus Yohanes Paulus II di Mexico menuntut landreform dan di Haiti mengeritik korupsi pemerintahan Duvalier. ${ }^{21}$

Ajakan untuk melakukan tindakan profetis sangat jelas dikemukakan oleh Paus Yohanes Paulus II di dalam Sollicitudo Rei Socialis 8. Bertindak secara profetis berarti menerapkan Sabda Allah pada hidup manusia dan masyarakat dan pada realitas duniawi

${ }^{21}$ Franz Magnis-Suseno, "Iman dan Politik", dalam Eduard R. Doppo, Keprihatinan Sosial Gereja, Op. Cit., hlm. 39. 
yang berkaitan dengannya. Gereja harus mempermaklumkan Sabda Allah sedemikian rupa sehingga berupa pedang bermata dua (Wahyu 2,12) yang memisahkan antara yang benar dan yang tidak benar, antara yang adil di hadapan Allah dan yang tidak.

Namun, tindakan profetis tidak tanpa kelemahan. Tindakan profestis tidak tanpa resiko: pertama, resiko mendapat tindakan perlawanan dengan kekuasaan atau kekerasan dari penguasa; kedua, resiko keliru mengartikan bisikan Roh. Resiko sosial, politik, dan hukum, bahkan ekonomi, dari tindakan profetis, pasti ada. Namun sebagai pengikut Kristus orang Kristen siap menanggung penderitaan sebagaimana Kristus sendiri menderita sampai mati di salib. Yang paling beresiko adalah yang kedua, yakni kita bisa keliru membaca tandatanda zaman dan keliru mengartikan bisikan Roh. Bahaya pun terbuka, atas nama membaca tanda-tanda zaman kita mengeritik pemerintahan sebagai tidak adil dan korup, padahal itu lebih dimotivasi oleh irihati, kecemburuan dan balas dendam pribadi, daripada sebuah niat yang luhur untuk memperbaiki situasi.

\section{Wujud Iman dalam "Tindakan Politis"}

Pertama-tama kita menjernihkan dulu istilah politik. Sampai sekarang masih ada umat yang memahami politik sebagai permainan kotor, tipu muslihat, siasat, pergolakan, perebutan kuasa, dan korupsi, singkatnya bernada negatif. Tentu kita tidak dapat membantah pemahaman itu, karena memang dalam kenyataan masyarakat mengalami seperti itu. Padahal menurut Konsili Vatikan II politik itu tidak kotor malah luhur. Kenapa luhur, karena hanya melalui politik bonum commune (kesejahteraan umum) diciptakan. Karena itu konsili memuji para politisi: "Gereja memandang layak dipuji dan dihormati kegiatan mereka, yang demi pengabdian kepada sesama membaktikan diri kepada kesejahteraan negara dan sanggup memikul beban kewajiban mereka".

Adapun penggunaan istilah politik di sini tidak hanya menyangkut mereka yang memiliki panggilan khusus dalam bidang politik yaitu para politisi melainkan menyangkut semua warga masyarakat. Tindakan apa saja seorang warga masyarakat di ranah publik selalu 
bersifat politis. $^{22}$ Karena, manusia miskin karena tindakan itu sama sekali memiliki dimensi politis (sosial). Dan tidak menghapus akar dari kemiskinan; dimensi politis manusia adalah dimensi masyarakat sebagai keseluruhan. Karena itu suatu tindakan disebut politis manakala tindakan itu dilakukan dalam kerangka acuan yang berorientasi pada masyarakat, tetapi bukan masyarakat sebagai kelompok ini dan itu, melainkan masyarakat sebagai keseluruhan. Karena itu, tindakan seorang politisi hanya dapat disebut tindakan politis sejauh tindakan itu menyangkut masyarakat sebagai keseluruhan. Juga seorang bukan politisi mengambil suatu sikap politis manakala ia dalam sikap itu mengacu pada masyarakat sebagai keseluruhan. ${ }^{23}$

Ketidakadilan dan korupsi yang menyebabkan kemiskinan itu tentu tidak cukup dengan tindakan moral dengan mewartakan pertobatan individual; juga tidak memadai hanya dengan tindakan karya amal untuk membantu orang

22 Sesungguhnya, Ajaran Sosial Gereja sejak Rerum Novarum (1891) sampai dengan Ajaran Sosial Gereja sekarang Gereja berbicara tentang dimensi politis kehidupan iman. Paus Paulus VI, pada tahun 1976, dalam Octogesima Adveniens 46, mendesak orang Kristen memikul tanggung jawab politik, sebab "politik merupakan cara yang menantang - untuk memikul tugas semua orang Kristen, yang melayani orang lain",

${ }^{23}$ Franz Magnis-Suseno, Etika Politik. Prinsip-prinsip Moral Dasar Kenegaraan Modern, Jakarta: Gramedia, 1999, hlm. 19-20. dan juga tidak dapat hanya dengan tindakan profetis melalui kritik pedas di mimbar Gereja atau tulisan di media karena mudah tergelincir kepada bahaya mengatasnamakan kehendak Allah padahal kehendak pribadi. Ketiga tindakan itu sesungguhnya secara implisit selalu menuntut atau mengandung suatu tindakan politis. Karena persoalan ketidakadilan dan korupsi bukanlah melulu persoalan individual melainkan persoalan anggota masyarakat yang berdimensi politis, yaitu persoalan tindakan anggota masyarakat yang menyangkut masyarakat sebagai keseluruhan.

Pertobatan sosial, misalnya, betul bahwa ketidakadilan sosial itu dilakukan tidak oleh masyarakat sebagai keseluruhan melainkan oleh individu dalam msayarakat, namun tindakan individu itu justru dikondisikan oleh masyarakat dan baru ditambah unsur kehendak pribadinya. Karena itu, perubahan struktural tidak cukup dengan seruan moral agar setiap orang bertobat: tidak boleh memeras, mencuri, dan korupsi. Bagaimanapun perubahan 
struktural menuntut suatu tindakan politis.

Paus Beneddiktus, dalam Deus Caritas est 28, menulis: “...bukanlah tugas Gereja untuk secara politis mewujudkan sendiri ajaran ini. Ia mau mengabdi pembentukan hati nurani dalam politik dan membantu agar keterbukaan bagi tuntutan sejati atas keadilan berkembang dan sekaligus kesediaan bertindak menurutnya, meskipun bertentangan dengan kepentingan yang meluas". Menurut paus membangun tatanan masyarakat dan negara yang adil bukanlah tugas langsung Gereja melainkan tugas dari tatanan politik. Lalu apa tugas Gereja. Lalu paus melanjutkan demikian: "Namun karena sekaligus merupakan tugas kemanusiaan yang asasi, maka Gereja mempunyai kewajiban, dengan caranya sendiri dengan pemurnian akalbudi dan pembentukan etis memberikan sumbangannya, agar tuntutan keadilan menjadi mudah dipahami dan diwujudkan secara politis".
Sedangkan Paus Fransiskus ${ }^{24}$ bicara tentang penghapusan korupsi: "Jika korupsi tidak diperangi secara terbuka, cepat atau lambat setiap orang akan menjadi kaki tangannya, dan akan berakhir dengan rusaknya eksistensi kita". Paus sungguh sadar bahwa menghapus korupsi tidak cukup dengan menggugat hati nurani melalui seruan pertobatan. Tindakan yang tepat adalah menanggapi secara terbuka dan itu hanya mungkin dalam dua tindakan, yakni tindakan profetis dan tindakan politis. Tetapi dengan kelemahan yang cukup mendasar dari tindakan profetis yaitu bisa keliru menafsir bisikan Roh, maka tindakan politis tetap merupakan tindakan yang paling memungkinkan untuk merubah kondisi masyarakat agar menjadi lebih manusiawi. Akan tetapi, awam Katolik justru apatis dengan yang namanya politik, karena bagi mereka politik itu bobrok, penuh kebusukan dan penipuan.

Menyadari apatisme seperti itu, Paus Fransiskus, dalam Evangilii Gaudium 205, menulis: "Politik, meskipun seringkali dicela, tetap menjadi panggilan luhur dan salah satu

\footnotetext{
${ }^{24}$ Bulla Misericordiae Vultus 19.
} 
bentuk paling bernilai dari amal kasih". Tetapi paus menambahkan bahwa politik itu memang luhur dan paling bernilai dari amal kasih namun sejauh mengusahakan kesejahteraan umum. Lalu ia melanjutkan seruannya: "Saya mohon kepada Tuhan agar memberi kita lebih banyak politisi yang sungguhsungguh memiliki kepedulian kepada masyarakat, rakyat, dan kehidupan orang-orang miskin".

\section{Kesimpulan}

Akhirnya, sebagai seorang awam Katolik saya mencatat satu hal penting ini, bahwa kaum awam dalam usaha menghapus ketidakadilan dan korupsi sebagai suatu bencana sosial, haruslah selalu mengarahkan diri pada ajakan dan patokan bertindak sebagaimana diajarkan oleh Injil dan Ajaran Sosial Gereja. Injil memang tidak menawarkan pemecahan konkret terhadap masalah sosial yang kita hadapi, karena Injil bukanlah buku hukum seperti kerangka negara hukum. Namun demikian, Injil memberikan inspirasi dan pengarahan bagi kita dalam bertindak demi perubahan situasi. Demikian juga Ajaran
Sosial Gereja tidak memiliki kompetensi teknis untuk memecahkan masalahmasalah sosial masyarakat. Keahlian dan wewenang Gereja tidak terletak di bidang sosial, ekonomi, dan politik. Karena itu Gereja tidak mempunyai pandangan tentang sistem ekonomi dan politik yang paling tepat dan tidak dapat mengajukan program-program penghapusan masalah sosial.

Lalu, apa tugas dan wewenang Gereja sebagai institusi? Gereja bertugas dan berwewenang memberikan inspirasi dan orientasi bertindak kaum beriman dalam masyarakat dan membangun prinsip-prinsip pembimbing bagi seluruh anggota Gereja untuk bertindak secara nyata merubah kondisi masyarakat. Struktur masyarakat yang tidak adil dan korup itu, bagaimanapun harus diresapi oleh hukum dasar Kristus yakni cinta kasih, hal mana sama dengan usaha penegakan keadilan dan peniadaan korupsi.

Kaum awam sebagai kelompok terbesar dalam keanggotaan Gereja dan sekaligus sebagai yang terlibat langsung dalam masalah sosial itu, dipanggil untuk mewujudkan suatu masyarakat yang adil dan bebas korupsi. Bagi awam 
Katolik masalah ketidakadilan dan korupsi bukanlah hanya sebagai soal politik atau soal hukum melainkan juga soal iman. Awam Katolik, kalau mereka sungguh beriman, maka mereka tidak boleh cuci tangan terhadap masalah ketidakadilan dan korupsi. Usaha menghapus ketidakadilan dan korupsi adalah wujud dari perutusan diakonia kaum awam pada kondisi bangsa kita saat ini.

\section{Daftar referensi}

Banawiratma, J.B \& J. Mueller, SJ, Berteologi Sosial Lintas Ilmu. Kemiskinan sebagai Tantangan Hidup Bersama, Yogyakarta: Kanisius, 1993.

Dokumen Konsili Vatikan (terj. R. Hardawiryana, SJ), Jakarta: OBOR, 2017.

Gitowiratmo, Stphanus Pr, "Gereja Kaum Awam sebagai Proses Perwujudan Iman", dalam Teologi dan Spiritualitas, Orientasi Baru, Pustaka Filsafat dan Teologi, No. 8, Yogyakarta: Kanisius, 1994.

Hadiwardoyo, Al. Purwa, "Pewartaan Injil dan Keadilan", dalam: JB Banawiratma, SJ, Gereja dan Masyarakat, Yogyakarta: Kanisius, 1986.

Heinz Psche, Karl, SVD, Etika Kristiani Jilid II Kewajiban Moral dalam Hidup Keagamaan (terj. Alex Armanjaya, Yosef M. Florisan, G. Kirchberger), Maumere: Ledalero, 2003.
Jacobs, T, Kostitusi Dogamtis "Lumen Gentium” mengenai Gereja. Terjemahan Introduksi Komentar, Jilid III, Yogyakarta: Kanisius, 1974.

Kieser, Bernard, SJ, Moral Sosial. Keterlibatan Umat dalam Hidup Bermasyarakat, Yogyakarta: Kanisisus, 1987.

Kirchbeger, Georg Allah Mengguat. Sebuah Dogmatik Kristen, Maumere: Ledalero, 2007.

Komisi Kepausan untuk Keadilan dan Perdamaian, Kompedium Ajaran Sosial Gereja (terj. Yosef Maria Florisan, Paul Budi Kleden, Otto Gusti Madung), Maumere: Ledalero, 2009.

Magnis-Suseno, Franz, "Iman dan Politik", dalam: Eduard R. Dopppo (ed.), Keprihatinan Sosial Gereja: Yogyakarta: Kanisius, 1992.

Magnis-Suseno, Franz, Etika Politik. Prinsip-prinsip Moral Dasar Kenegaraan Modern, Jakarta: Gramedia, 1999.

Mueller, J., SJ, "Pewartaan Injil dan Penegakan Keadilan Tugas Perutusan Gereja di Tengah Masalah-masalah Sosial, dalan: Eduard R. Dopo (ed.), Keprihatinan Sosial Gereja: Yogyakarta: Kanisius, 1992.

Seri Dokumen Gerejawi Edisi Khusus, Kumpulan-kumpulan Ajaran-Ajaran Sosial Gereja Tahun 1891-1991 Dari Rerum Novarum sampai dengan Centesimus Annus, Jakarta: Dokpen KWI, 1999.

Van der Weiden, W., MSF, "Kritik Sosial dari Nabi-nabi: dalam: J.B. Banawiratma, SJ (ed.), Aspek-aspek Teologi Sosial, Yogyakarta: Kanisius, 1988. 
LUMEN VERITATIS: Jurnal Filsafat dan Teologi, Volume. 10 Nomor 2 April 2020

pSSN 1978-3469; eISSN 2657-1927 